\title{
NARRATIVAS DE MIM: MEMÓRIAS DANÇANTES
}

\section{ANA CRISTINA CARVALHO PEREIRA}

https://orcid.org/0000-0003-2421-6757

Universidade Federal de Minas Gerais

RESUMO A partir de uma perspectiva autobiográfica este artigo reflete sobre o percurso formativo de uma artista-professora-pesquisadora de Dança desde o ensino não-formal até o ensino superior. Ligando o passado, o presente e o futuro, narra fragmentos de experiências estéticas desde a infância até a atuação profissional numa universidade pública, no âmbito do ensino, pesquisa e extensão. É uma construção biográfica de alguém que atende ao chamado da Arte significando assumi-la em todas as suas dimensões, e em todas as relações que esta poderia propiciar e que se cruzam entre momentos vividos na infância, na prática artística, na docência e na investigação. 0 texto apresenta a (re)significação das imagens, lembranças, recordações a partir do referencial teórico de autores como DeloryMomberger (2006, 2012), Josso (2004) e Vianna (1990). Conclui-se que pela singularidade desta história de vida, acessos a formações, acervos culturais e atuação artística criaram um repertório e um modo próprio de ser docente na área da Dança.

Palavras-chave: Narrativas. Dança. Artista-professora-pesquisadora. Percurso formativo.

\section{ABSTRACT NARRATIVES OF ME: DANCING MEMORIES}

From an autobiographical perspective this article reflects on the formative path of a dance artist-teacher-researcher from non-formal education to higher education. Bridging the past, the present and the future, narrates fragments of aesthetic experiences from childhood to professional practice in a public university, in the field of teaching, research and extension. It is a biographical construction of someone who responds to the call of Art meaning to assume it in all its dimensions, and in all the relationships that it could provide and that intersect between moments lived in childhood, artistic practice, teaching and research. The text presents the (re) meaning of images, memories, recoveries from the theoretical framework of authors such as Delory-Momberger $(2006,2012)$, Josso 
(2004) and Vianna (1990). It is concluded that due to the uniqueness of this life story, access to training, cultural collections and artistic performance created a repertoire and a way of being a teacher in the area of dance.

Keywords: Narratives. Dance. Artist-teacher-researcher. Formative journey.

\section{RESUMEN NARRATIVAS DE Mİ: MEMORIAS DE DANZANTES}

Desde una perspectiva autobiográfica, este artículo reflexiona sobre el camino formativo de un artista-profesor-investigadora de danza desde la educación no formal hasta la educación superior. Uniendo el pasado, el presente y el futuro, narra fragmentos de experiencias estéticas desde la infancia hasta la práctica profesional en una universidad pública, en el campo de la enseñanza, la investigación y la extensión. Es una construcción biográfica de alguien que responde a la llamada del arte que significa asumirlo en todas sus dimensiones, y en todas las relaciones que podría proporcionar y que se cruzan entre los momentos vividos en la infancia, la práctica artística, la docencia y la investigación. El texto presenta el (re)significado de imágenes, remembranzas, recuerdos del referencial teórico de autores como Delory-Momberger (2006, 2012), Josso (2004) y Vianna (1990). Se concluye que, debido a la singularidad de esta historia de vida, el acceso a la formaciones, acervos culturales y actuación artística crearon un repertorio y un modo propio de ser maestro en el área de la danza.

Palabras clave: Narrativas. Danza. Artista-profesora-investigadora. Camino formativo.

\section{Introdução}

Neste artigo, como intérprete da minha trajetória profissional construí representações, categorizações que me permitiram narrar a mim mesmo dando visibilidade a uma narrativa que define meu lugar a partir da ressonância das minhas experiências e criando um elo entre meu passado, presente e futuro dando sentido a minha existência e reconhecendo que o sujeito se constitui em práticas no e com o corpo que, longe de ser simples "suporte", é aquilo pelo qual e no qual sua identidade encontra sua forma. Para Delory-Momberger
[...] se essa dimensão da temporalidade é, com certeza, essencial na constituição da experiência e no trabalho biográfico que ela implica, o espaço, a começar [...] pelo nosso próprio corpo [...] é também constitutivo da experiência, um lugar de constituição das representações de si e dos outros. (2012a, p. 65).

Esta narrativa é fruto de uma construção ao mesmo tempo pessoal, individual e coletiva que envolvem minhas experiências a partir de paisagens do corpo: gesto, subjetividade, dança, educação. 
Considerando que o dançar e o ensinar dança constituem conhecimentos inerentes à experiência de aprendizado no e pelo corpo, apresento os caminhos que foram e estão sendo trilhadas por mim. Vivências do meu corpo ao longo de minha história que se materializaram em minha identidade profissional. Experiências particulares, únicas, integrantes de uma tecitura viva, construindo um sentido para minha vida.

Atender o chamado da Arte da Dança significou assumi-la em todas as suas dimensões e relações que esta poderia propiciar. Foi ser tomada de coragem para trilhar e construir um caminho. Assim,

Na apresentação de si mesmo por meio do relato, o indivíduo se faz intérprete dele mesmo: ele explicita as etapas e os campos temáticos de sua própria construção biográfica. Ele também é intérprete do mundo histórico e social que é o dele: ele constrói figuras, representações, valores (Demazière, 1997), considerando que é no relato que ele faz suas experiências de que o sujeito produz categorizações que the permitem apropriar-se do mundo social e nele definir seu lugar (DELORY-MOMBERGER, 2006, p. 369).

Apresento aqui fragmentos da trajetória que percorri na construção de um trabalho profissional que se dá inicialmente fora e posteriormente dentro da Universidade. Trago algumas experiencias do meu fazer que me levaram ao meu atual momento de vida como docente-artista-pesquisadora, ligada a uma universidade pública.

\section{Narrativas de uma formação artística em dança}

A formação daquele que pretende se tornar um Profissional de Dança, em geral, inicia-se como estudante ainda na infância ou no início da adolescência. Desse modo também muito cedo, esse iniciante, tradicionalmente já co- meça a dar aulas em cursos livres. Enquanto dá suas aulas, ele não interrompe seu processo de formação técnica, até que tenha condições de se inserir em algum pequeno grupo ou companhia de dança, ou mesmo, numa produção independente de algum espetáculo de dança, após submeter-se a audições e concursos. Assim, como bailarino e professor, ele aos poucos se insere no mercado de trabalho. Outra possibilidade é considerar ainda que essa pessoa pode solicitar uma audição em seu Sindicato de Classe e receber, caso seja aprovado, o seu registro profissional, podendo exercer legalmente suas atividades de bailarino, coreógrafo e professor de dança em espaços não-formais de educação.

Mais recentemente o ensino formal se apresenta como um novo campo que se abre para o Profissional de Dança desde que formado no curso a Licenciatura em Dança.

\section{Primeiros passos: corpo expressivo}

Nasci no ano de 1959 em São Paulo, capital. Neste período, muitas transformações começam acontecer. Entre elas podemos citar a grande mudança na mídia televisiva e jornalística brasileira que passa a investir em outros meios de propaganda para além das famosas TVs Moças como Regina Duarte. A nova proposta importa o modelo americano e lança os comerciais infantis.

Foi neste contexto que, aos dois anos e meio de idade, em 1962, fui selecionada com outras três crianças, para fazer o Primeiro Comercial Infantil da TV Brasileira de veiculação nacional da Farinha Láctea Nestlé, o comercial carinhosamente apelidado de "comercial das comadrinhas". No mesmo ano fui convidada para participar do lançamento da Boneca Amiguinha da Estrela nos jornais de veiculação nacional. 
Figura 01 - Revista São Paulo na TV, 1962
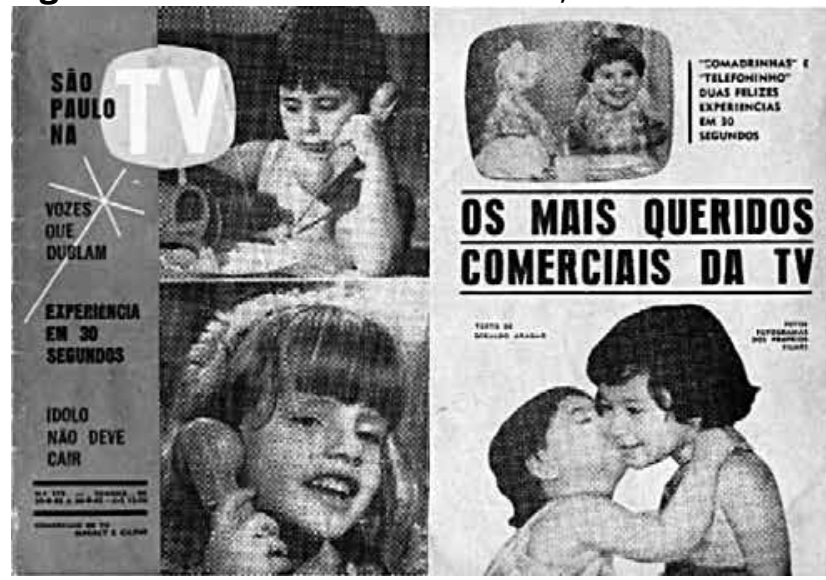

Fonte: Acervo da autora
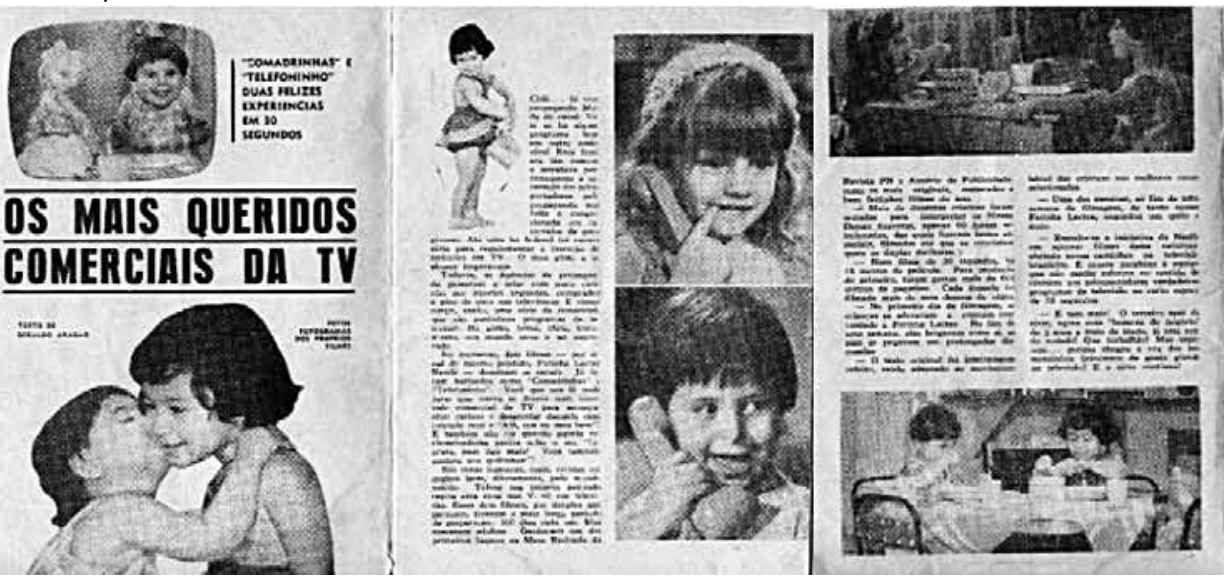

Figura 02 - Lançamento da Boneca Amiguinha da Estrela, Jornal Folha de São Paulo, 1961

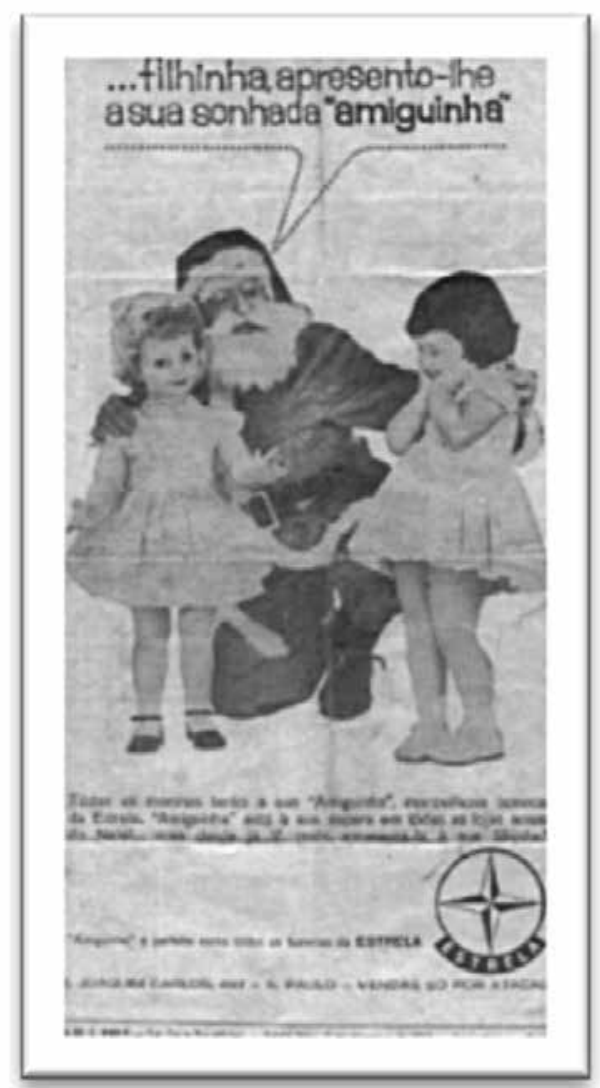

Fonte: Acervo da autora

Vinte anos depois, em 1982, a produção do Programa Vídeo Show entra em contato querendo fazer um documentário sobre o Primeiro Comercial Infantil da TV Brasileira. Queriam saber o que aconteceu com as comadrinhas que participaram da campanha da Farinha Láctea Nestlé. Mas como somente eu prossegui na carreira artística, conseguiram me loca-

lizar nos registros do Sindicato dos Artistas e Técnicos em Espetáculos de Diversão do Estado do Rio de Janeiro (SATED-RJ). E foi assim que neste mesmo ano participei do documentário do Vídeo Show que apresentava minha trajetória artística antes e o depois do primeiro comercial da Farinha Láctea Nestlé: as "comadrinhas".

Retomar os registros do comercial de TV, da revista e dos recortes de jornais e da entrevista no programa Vídeo Show foi um momento muito marcante pois constatei que apesar de muito pequena, com apenas dois anos e meio, no comercial já usava a minha linguagem corporal para ilustrar o texto narrado por um adulto. Eu já era capaz de usar minha expressividade num comercial, isto é, minha primeira experiência em "cena". Reconheci neste acontecimento a experiência fundadora da minha trajetória como Artista da Dança. Uma "recordação-referência" da minha trajetória, pois segundo Josso (2004, p. 40) "falar de recordações -referências é dizer, de imediato, que elas são simbólicas do que o autor compreende como elementos constitutivos da sua formação".

\section{Construção do corpo cênico}

Em 1968 me mudo com a família para Belo Horizonte. Em 1975 iniciei meus estudos de dança na Escola de Dança do Colégio Pio XII com a 
professora Graziela Rodrigues. Ao rever minhas fotos e jornais encontro a foto do meu primeiro festival de dança nesta mesma escola. Desde então foram muitos anos de dedicação, pois na formação em dança não pode se dar saltos no tempo. Como dizia o mestre Klaus Vianna (VIANNA, 1990, p. 39), "existe o dia, a noite, a semana, o mês, o ano, você não tem como suprimir o tempo, não posso pular uma noite, não posso ir contra a natureza, a natureza do meu corpo. [...] o aprendizado exige tempo e esse tempo precisa ser consciente".

Figura 03 - Espetáculo da Escola de Dança do Colégio Pio XII, 1976

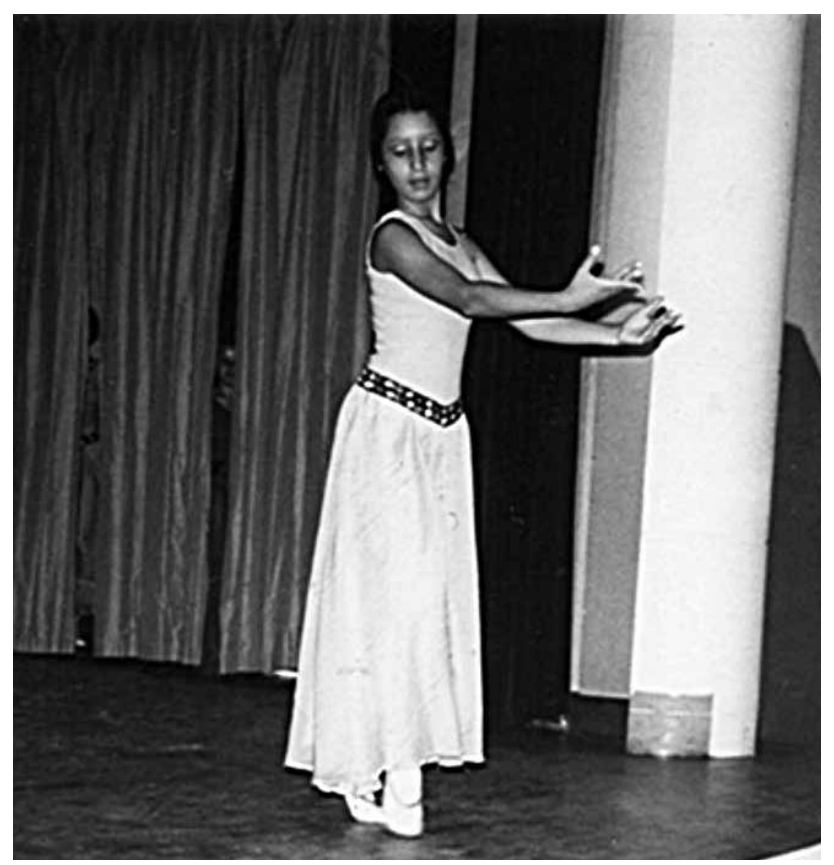

Fonte: Acervo da autora

Logo em seguida ingressei, em 1977, no Studio Anna Pavlova, onde se deu minha formação como Artista da Dança e minha formação humana, pois as diretoras Dulce Beltrão e Sylva Calvo tinham como proposta ser "Uma escola de dança para a vida inteira"

Nesta escola, além dos meus estudos durante muitos anos com as fundadoras e diretoras Beltrão e Calvo, fui incentivada a conhecer e estudar com outros professores, seja como convidado pela direção da escola para ministrar cursos, seja nos incentivando a fazer cur- sos de atualização em outras escolas e até em outros estados. Vários caminhos e possibilidades de formação em dança foram apresentados durante o meu percurso. Tive oportunidade de fazer aulas com professores considerados referência no ensino da dança como: Roseli Rodrigues, Rebeca Torossian, Renato Vieira, Jairo Sette, Marcia Barros, Marly Tavares, Gilson Sacramento, Euzébio Lobo, Vilma Vermon (Jazz); Bettina Bellomo, José Roberto Pereira, Tonny Abbott, Norma Binaghi, Ismael Guiser (Clássico); Klauss Vianna, Angel Vianna, Martine Époque, Paul André Fortier, Sylvie Pinard, Marluce Guimarães Gomes (Moderno); Helena Katz e Gloria Reis (História da Dança).

Éramos incentivadas a buscar uma formação plural que contribuísse para construção da nossa identidade como Artista de Dança. "Um gesto, uma dança, um movimento do ser..." diziam as diretoras Beltrão e Calvo.

Dulce Beltrão, uma das diretoras do Studio Anna Pavlova teve em sua trajetória profissional contato com diferentes linguagens artísticas que por sua vez influenciaram seu trabalho nos processos de criação em dança no Studio. Nesta perspectiva interdisciplinar, uma dessas aproximações possibilitou uma forte interlocução da Dança com a área de Teatro potencializando a expressividade dramática dos bailarinos nos espetáculos. Em várias montagens de espetáculos tive oportunidade de trabalhar com a direção conjunta de Beltrão e diretores teatrais como: Décio Noviello e Jota Dangelo. Esta característica é que futuramente dá o nome ao Grupo Profissional de Dança Baleteatro Minas do qual fiz parte.

Um dos momentos significativos na minha formação foi minha participação nos Festivais de Inverno de Ouro Preto, nos anos de 1976 e 1977, considerado um dos movimentos culturais de vanguarda no país. 0 objetivo era promover cursos intensivos no período de férias escolares de julho, destinados aos alunos, ar- 
tistas e professores de Arte de várias regiões do Brasil e do exterior promovendo encontros, fomentando e gestando novas propostas e ações no âmbito das Artes.

No Festival Inverno de Ouro Preto de 1976 tive oportunidade de frequentar as oficinas de Angel Vianna, Graciela Figueroa, Heder Parente Pessoa e Ruth Rachou. Esta experiência de imersão no ambiente intenso do festival me marcou profundamente. Tive a possibilidade de ter contato com um novo entendimento de dança. Um movimento de vanguarda onde artistas apresentavam suas criações, consideradas subversivas no contexto da ditadura militar, pois buscavam outra proposta de organização corporal para construção de um corpo cênico. Uma proposta diferenciada que subverteu os padrões estéticos reconhecidos na dança em Belo Horizonte até então. Um movimento que se caracterizava pela liberdade criativa.

Como exemplo deste contexto, durante o festival a professora Angel Vianna promove um espetáculo, carinhosamente chamado de "A dança das cadeiras", nas escadarias da Igreja Nossa Senhora do Carmo de Ouro Preto. Em cena tínhamos como referência os elementos da improvisação e o uso de cadeiras como objeto cênico. Não havia passos pré-estabelecidos e sim a participação ativa de todos em cena num processo de criação coletiva!

Figura 04 - Dança das Cadeiras. Oficina de Angel Viana. Escadaria da Igreja Nossa Senhora do Carmo, em Ouro Preto

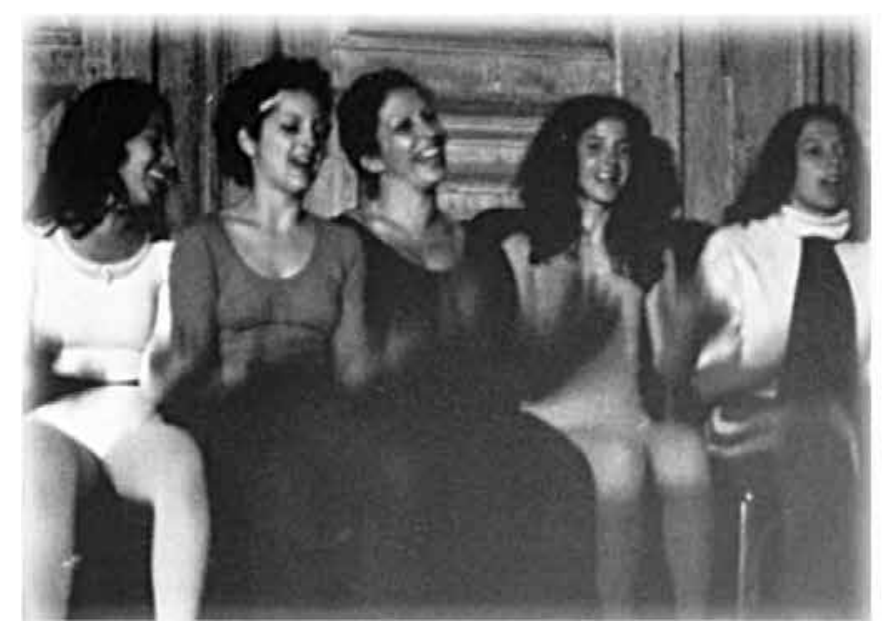

Fonte: Acervo da autora

Tempos depois passo a dar aulas no Studio Núcleo Artístico e participo, em 1982, do intercâmbio na Official School of Joffrey Ballet. Destaco este momento como uma importante etapa na minha formação a minha. Além dos cursos de aperfeiçoamento entre os anos de 1982 a 1985, onde tive oportunidade de ter aulas com mestres como Franck Hatched, Phil Black, Jose Meier, Jojo Smith, Michael Owens, De Marco, entre outros.

Esta experiência fora do Brasil foi transformadora à medida que possibilitou o acesso ao um universo dançante inigualável. Encontrei

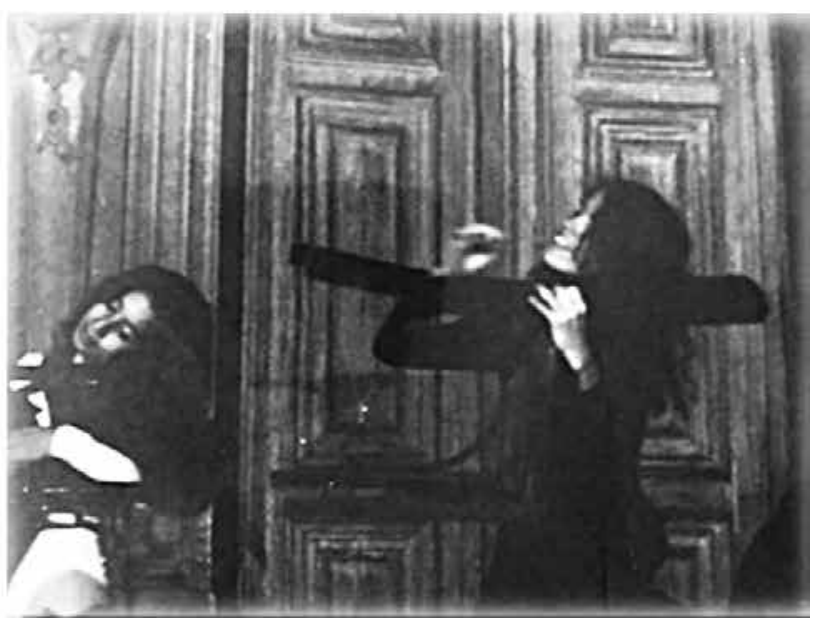

uma grande oferta de diferentes cursos de diferentes estilos de dança que promoviam uma formação diferenciada aos bailarinos ao mesmo tempo que constatei vários musicais que estavam em cartaz por mais de dez anos, configurando um amplo mercado de trabalho para os bailarinos.

Hoje vejo que esta experiência foi um marco em minha trajetória, pois quando volto pro Brasil, apesar de toda dificuldade e da resistência da minha família, assumo e escolho de forma consciente a Dança como minha profissão! 
Figura 05 - Aula de clássico no Intercâmbio Cultural

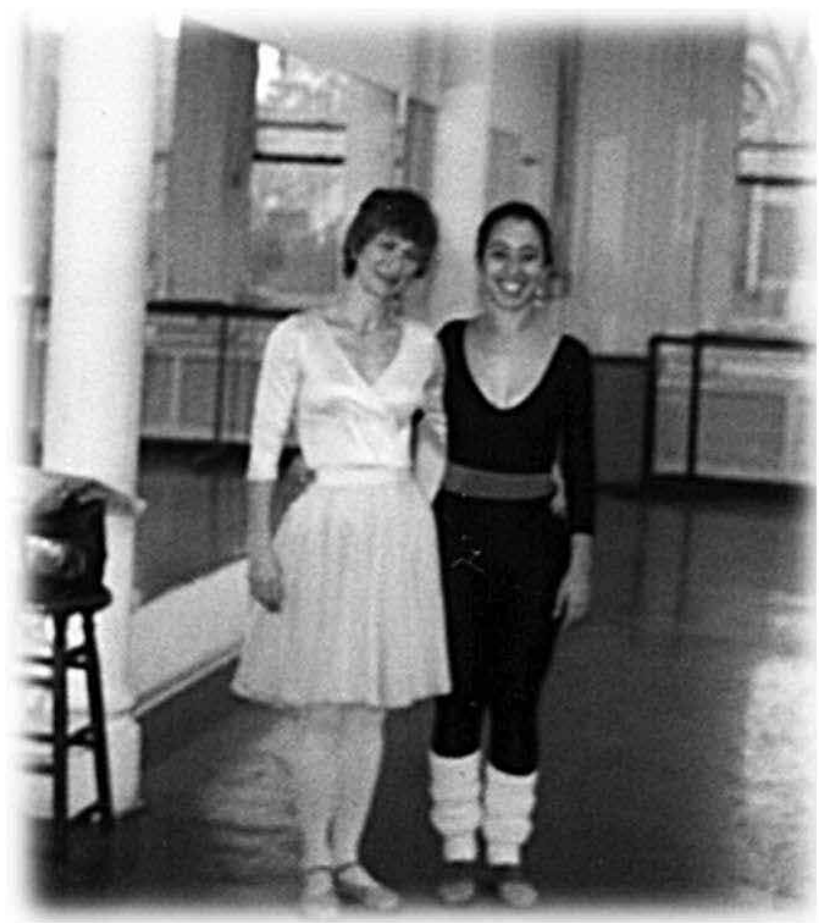

Fonte: Acervo da autora

\section{Bailarina: corpo cênico}

Durante todo este processo de formação a dança foi se tornando "adulta em mim", meus movimentos eram resultado de um processo consciente e intencional. Segundo Klauss Vianna, nesse processo,

À medida que trabalhamos, é preciso buscar a origem, a essência, a história dos gestos - fugindo da repetição mecânica de formas vazias e pré-fabricadas. Só assim o trabalho resultará em uma criação original, em uma técnica que é meio e não fim, pois a técnica só tem utilidade quando se transforma em uma segunda natureza do artista. (VIANNA, 1990, p. 58).

Como bailarina intérprete, trabalhei com vários grupos e companhias de dança cujas montagens e trabalhos foram apresentados em várias cidades brasileiras. Em 1979, pela primeira vez, assino um contrato como bailarina profissional para compor o corpo de baile da peça Saltimbancos em Belo Horizonte. Era o reconhecimento da minha escolha profissional!

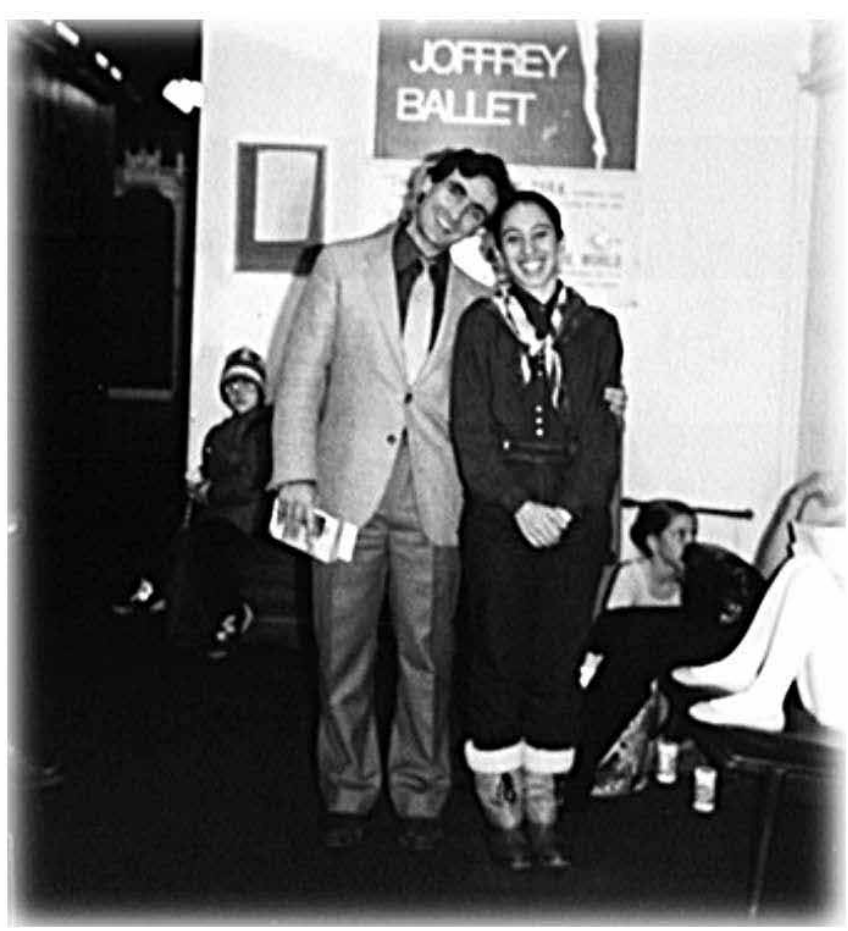

Figura 06 - Espetáculo Saltimbancos, Teatro ICBEU, 1979

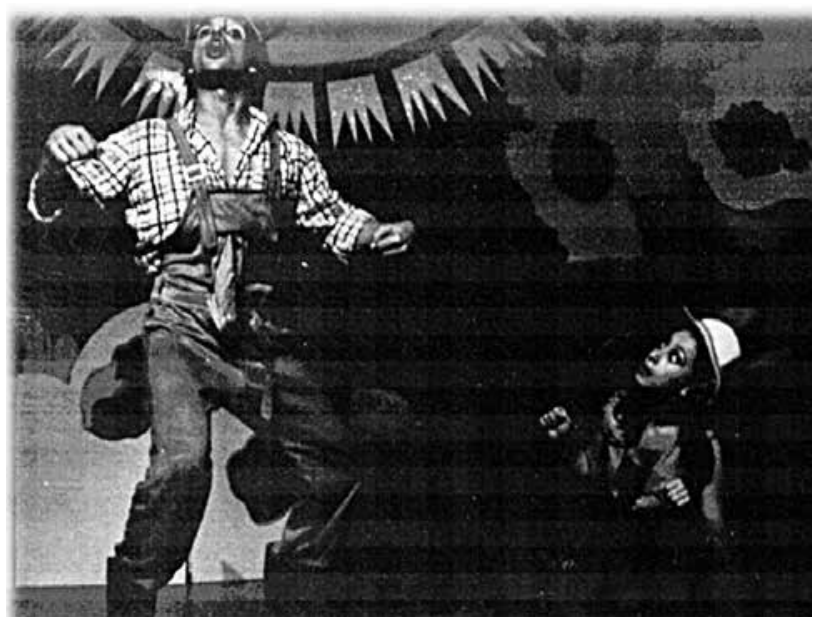

Fonte: Acervo da autora

No meu trabalho como bailarina, na maioria das vezes, as coreografias eram criadas e apresentadas pelo outro: coreógrafo, diretor ou ensaiador. Não havia minha participação no processo criativo. Mas, mesmo dançando uma coreografia elaborada por outra pessoa, aos poucos, depois de muito ensaiar, e por trazer uma forte marca da expressividade dramática na minha maneira de dançar, buscava ir além da repetição mecânica dos passos imprimindo 
uma forte marca expressiva transformando-a em "minha dança". Era quando me sentia artista em toda a minha potência expressiva.

Em 1980, aos 20 anos de idade, em plena ditadura militar, vivi uma experiência transformadora, que neste processo de revisitar minha trajetória, considero um divisor de águas em minha carreira. Foi o contato direto e a experiência vivida com o mestre e diretor Klauss Viana. Como integrante do Grupo de Dança Baleteatro Minas participei do espetáculo "Inconfidência Mineira: onde tem bruxa tem fada" sob a direção e coreografia de Klauss Vianna, estrutura sonora de Cecília Conde, direção teatral de Paulo Grisolli e texto de Bartolomeu Queiroz. Klauss desconsiderava os métodos formais de dança da época e buscava nos próprios bailarinos e em seus corpos, uma pesquisa do movimento construir uma linguagem expressiva e criativa.

Nesta perspectiva, fomos levados a pesquisar nosso gesto e movimento espontâneo e livre que dependia da nossa maneira exclusiva de sentir e viver. Durante um ano, através de experimentos e oficinas de criação ele promo- veu um processo onde buscávamos o autoconhecimento de nossos corpos, potencialidades e limites, nosso conhecimento técnico. A partir desses laboratórios e vivências e dos movimentos propostos pelos bailarinos, Klauss criou um espetáculo de dança estruturado em cenas como do balé Lago dos Cisnes, ladainha, roque, procissão (que evolui e se transforma em samba), sons de uma pracinha pública, leitura de cartomantes, candomblé, tango e pomba-gira, assaltos do dia a dia nas ruas da cidade. Dançávamos exemplos vivos de nosso sincretismo, sangue e centelha de uma permanente ilusão brasileira, batizada esperança num momento político totalmente adverso. Com maestria, Klauss Vianna mesclou fragmentos de uma realidade social que mostra o jogo das estruturas sociais travestidas em Fadas para melhor instalar o império das Bruxas. Era uma quebra de paradigma que subvertia padrões estéticos de corpo, cena e coreografia da época e possuía um caráter contestador da realidade social e política do país, assumindo uma atitude de resistência.

Figura 07 - Programa do Espetáculo "Onde tem bruxa tem fada" - Direção: Klauss Vianna / Cecília Conde / Paulo Grisolli / Bartolomeu Queiroz, 1980
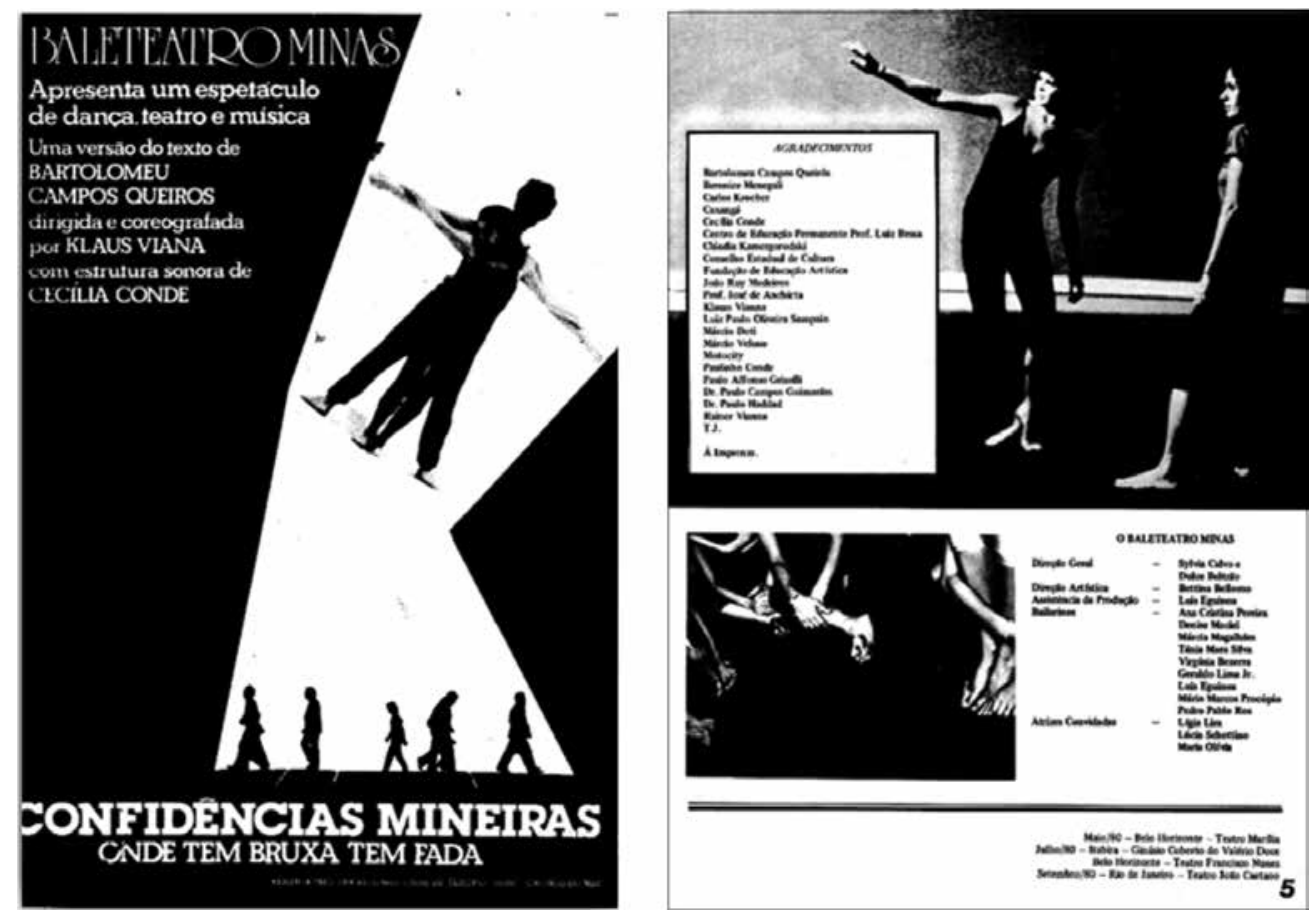

Fonte: Acervo da autora 
Figura 08 - Grupo de Dança Baleteatro Minas. Espetáculo "Onde tem bruxa tem fada"

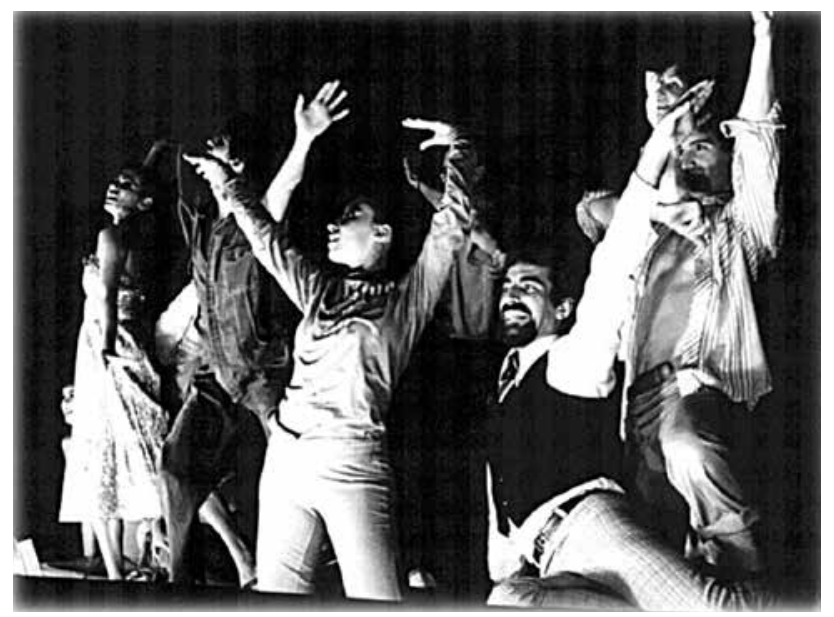

Fonte: Acervo da autora

A inovação proposta por Klauss Vianna, em 1980, pode ser considerada uma das bases para uma nova concepção de dança que se estrutura no Brasil desde então influenciando vários movimentos artísticos na dança e que dialoga diretamente com a proposta pedagógica do Curso de Dança - Licenciatura da EBA/ UFMG que atuo como docente desde 2010. Isto porque, Klauss Vianna foi um dos autores que serviu de referência para a elaboração do currículo deste curso, que têm em suas proposições entendimentos que auxiliam na construção de uma dança mais democrática e plural a partir do princípio da autoralidade que con- tribui para a busca da dança singular de cada aluno. Um espaço onde cada um pudessem buscar maneiras de "se dizer" através do movimento.

Ao longo da minha carreira foram muitos os ensaios, espetáculos, teatros, espaços alternativos, coreografias, coreógrafos, bailarinos, encontros e desencontros, diferentes estilos de dança, desafios e frustrações. Mas o mais importante disso tudo era que todas estas experiencias culminavam no objetivo maior do Artista de Dança - estar no palco! Rever algumas fotos desses momentos como bailarina me levou a criar um mundo repleto de significado assumindo "a concepção de indivíduo como ser singular, biográfico, que possui sua própria experiência" (DELORYMOMBERGER, 2012, p. 739). Afinal “[...] cada um de nós constrói e desenvolve uma cartografia que the é própria" (DELORY-MOMBERGER, 2012a, p. 74). À medida que fui reconhecendo nas fotos a minha maneira de estar no palco identifiquei uma forte marca de expressividade e presença cênica que nesse processo de narrar a mim mesmo me fazem reconhecer a forte influência das experiências com Dulce Beltrão e Klaus Vianna em minha formação inicial.

Figura 09 - Grupo de Dança do Studio Anna Pavlova, 1977
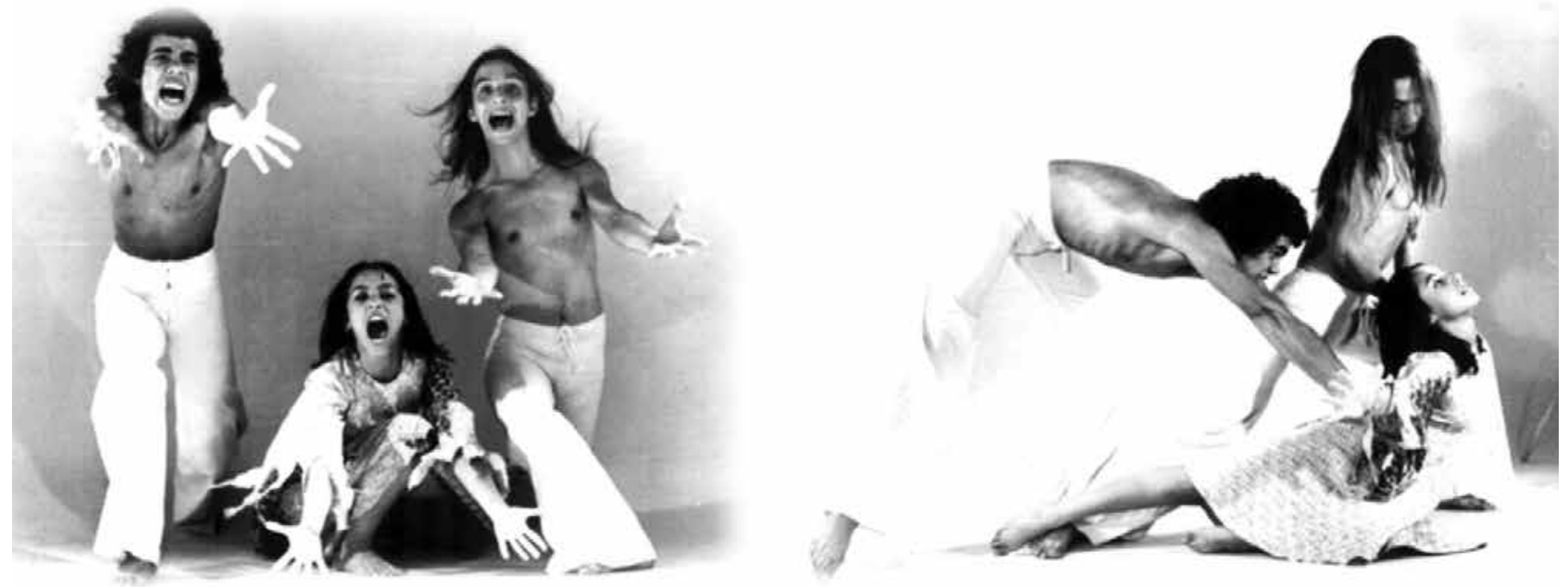

Fonte: Acervo da autora 
Figura 10 - Peça teatral Orquestra de Senhoritas, 1982
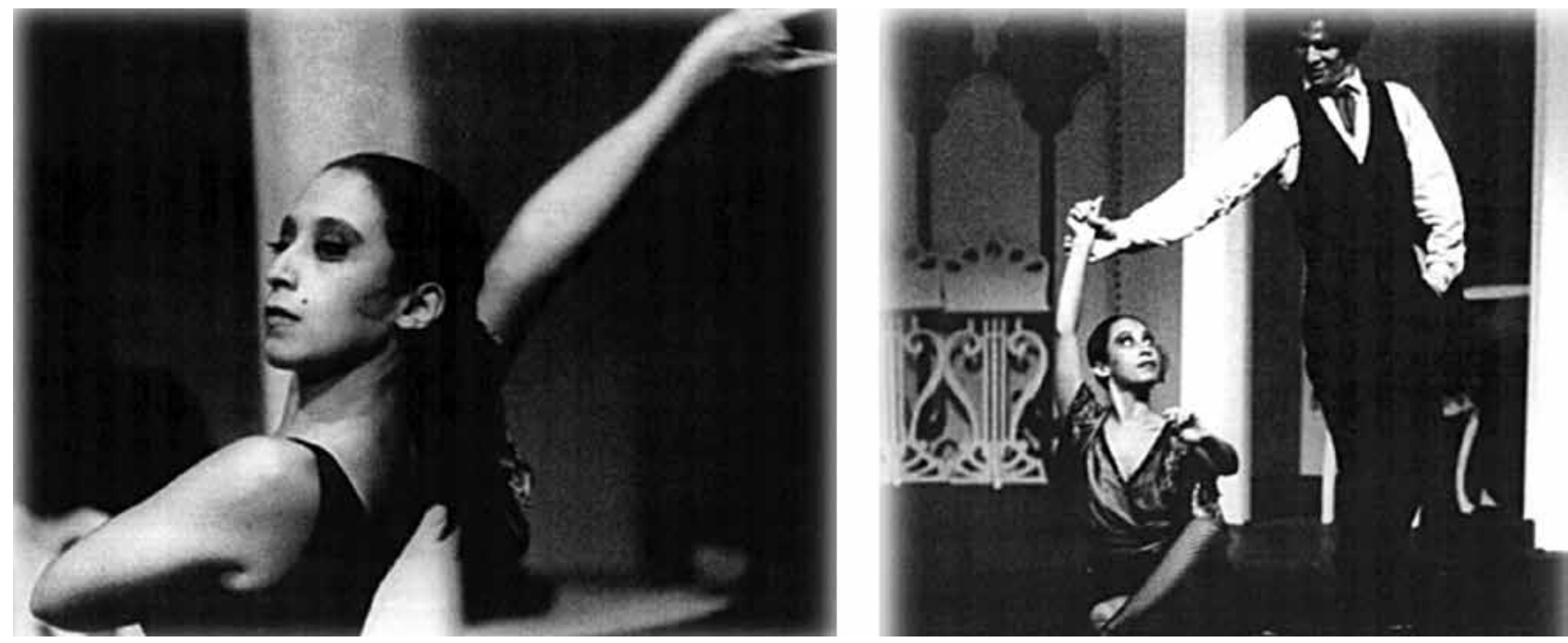

Fonte: Acervo da autora

Figura 11 - Studio Núcleo Artístico premiada no II Concurso Mineiro de Dança, Troféu de Ouro. Coreografia "Abrace a Vida", 1987

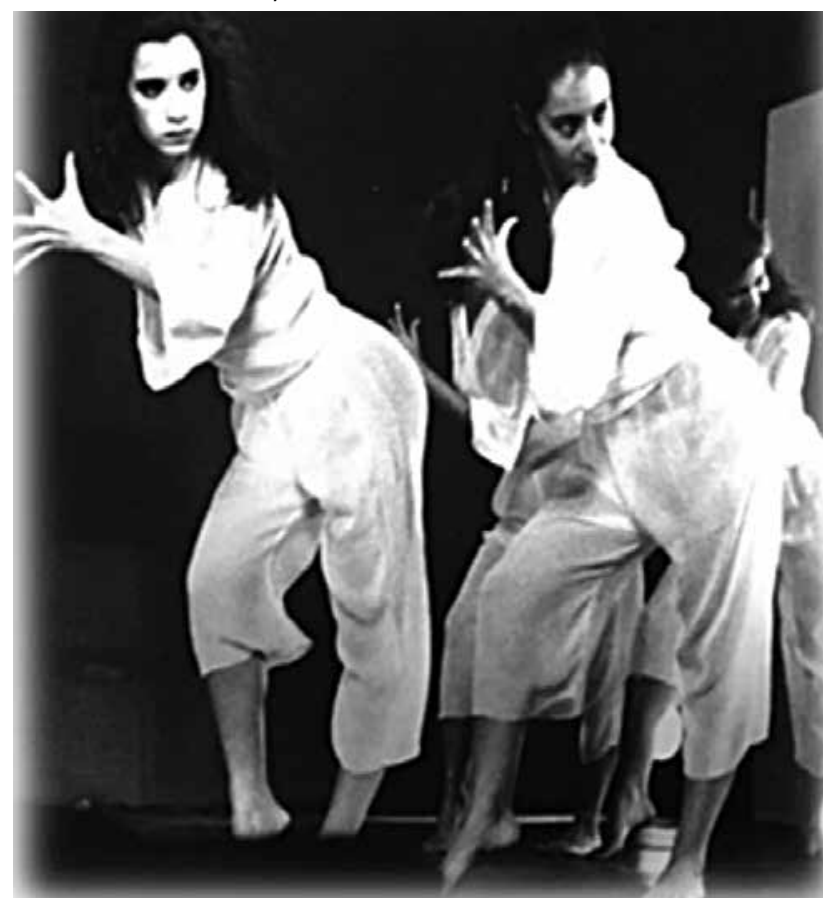

Fonte: Acervo da autora

Ensino de dança como

possibilidade de formação

humana e artística: professora

e coordenadora de escolas de dança

Comecei a ensinar dança aos 15 anos. Entre os anos de 1977 e 2001 atuei em várias escolas de
Figura 12 - Grupo de Dança Camaleão - Espetáculo “S.O.S. Brasil". Coreografia de Luiz Arrieta, 1989
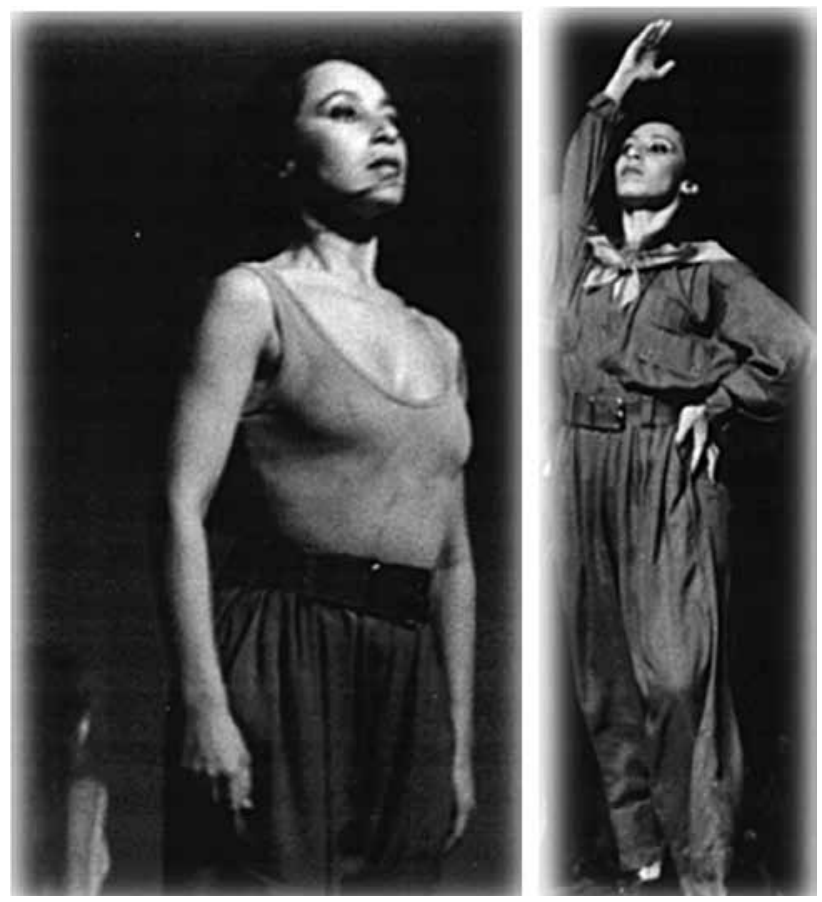

Fonte: Acervo da autora

dança de Belo Horizonte como professora e também como coordenadora. Entre elas destaco: Studio Anna Pavlova, Studio Meia Ponta, Studio Núcleo Artístico, Escola de Dança Primeiro Ato.

Ao rever as fotos dos festivais das escolas, das aulas e lembrar do meu trabalho como professora de dança reconheço como minha 
identidade de trabalho ir além de simplesmente ensinar passos e a repetição mecânica dos passos. Queria que as alunas encontrassem sua expressividade! Para além da técnica incentivava que buscassem maneiras de "se dizer" através do movimento. Queria que cada uma encontrasse a "sua dança"! "Um gesto, uma dança, um movimento do ser...", como sempre ouvi as diretoras Beltrão e Calvo falarem quando era aluna do Studio Anna Pavlova.

No período de 1997 a 2002, fui convidada para desenvolver um trabalho de dança no Colégio Nossa Senhora das Dores em Belo Horizonte. Esta experiência me possibilitou vivenciar a relação do ensino de Arte e o contexto escolar desenvolvendo atividades com crianças da Educação Infantil à 6a série do Ensino Fundamental. Nesse mesmo colégio, criei a Escola "Dança \& Arte" atuando como diretora e professora no Colégio Nossa Senhora das Dores, no extra turno, de 1997 a 2002. Era a possibilidade de desenvolver um trabalho numa perspectiva artística, pois até então, na maioria das escolas regulares a oferta da dança acontecia numa perspectiva associada ao esporte, lazer, e não, à Arte.

Hoje vejo que este momento foi a oportunidade de desenvolver uma proposta pedagógica a partir da identidade do meu trabalho estruturado ao longo da minha trajetória profissional com uma forte influência da minha formação no Studio Anna Pavlova e minha experiência com Klaus Vianna. Trabalhar com ênfase na autoralidade, no processo de criação, na consciência do próprio corpo, e na expressividade era a maneira de incentivar minhas alunas a encontrar a sua própria dança!

\section{O registro: memorias revisitadas}

Durante todo o meu processo de formação no Studio Anna Pavlova fui orientada e incentivada a registrar minha formação artística atra- vés de programas de espetáculo, jornais, fotos, etc. Isto porque, futuramente, todo este material seria a possibilidade de validar minha formação e trajetória profissional no momento da prova do Sindicato dos Artistas e Técnicos em Espetáculos de Diversões - SATED, para obter o meu registro profissional como artista. Nesse processo, além da prova prática tínhamos que apresentar um portfólio com a comprovação da nossa atuação artística como: certificados de cursos, programa de espetáculos, fotos, jornais, contratos e etc.

Neste aspecto, destaco também, minha participação em dois cursos sobre a temática História de Dança. O primeiro curso ministrado por Helena Katz, em 1991, intitulado "Três cenas de Dança" e o segundo ministrado por Glória Reis, em 1995, intitulado Curso da História da Dança. Estas experiências tiveram impactos que reverberam até hoje na minha atuação profissional, pois segundo Helena Katz (1991) "o que não está escrito não existe".

A partir dos ensinamentos desde minha formação no Studio Anna Pavlova e reforçado pela fala de Helena Katz, compreendi a importância do registro de todas as minhas ações como profissional e por esse motivo continuei registrando minha trajetória mesmo depois de obter meu registro profissional.

Compor uma cartografia por meio de imagens, jornais, fotos e vídeos pareceu-me ser ação potente para a apropriação da minha trajetória que me possibilitou um trabalho de organização transformando-os em fontes documentais e imagéticas para tecer esta "narrativa de mim" como um exercício interpretação e significação das experiências vividas no e com o meu corpo e assim dar forma a minha identidade profissional.

É impossivel não nos remetermos ao que propõe Josso (2004) quando diz que:

Elaborar a sua narrativa de vida e a partir daí, separar os materiais, compreendendo o que foi 
a formação, para em seguida, trabalhar na organização do sentido desses materiais ao construir uma história, a sua história, constitui uma prática de encenação do sujeito que torna-se autor ao pensar a sua vida na sua globalidade temporal, nas suas linhas de força, nos seus saberes adquiridos ou nas marcas do passado, assim como na perspectivação dos desafios do presente entre a memória revisitada e o futuro já atualizado, porque induzido por essa perspectiva temporal. Numa palavra, é entrar em cena um sujeito que se torna autor ao pensar na sua existencialidade. (JOSSO, 2004, p. 60).

\section{Diferentes caminhos percorridos:} narrativas de uma formação acadêmica

Muitos foram os caminhos percorridos. Com o objetivo de sistematizar minha experiência profissional como Professora de Dança em cursos livres e Artista da Dança, no ano de 1999, ingressei no Curso de Pedagogia Licenciatura Plena do Centro Universitário UNI-BH. Estava motivada pela concepção de Dança como área de conhecimento e como elemento constitutivo da formação do sujeito na Educação Básica a partir da Lei de Diretrizes e Bases da Educação Nacional - LDB -Lei no 9394/1996. Nela a Arte passou a ser disciplina regular obrigatória e a Dança, por meio dos Parâmetros Curriculares Nacionais - PCNs, (BRASIL, 1997), foi reconhecida como modalidade artística a ser ensinada na Educação Básica. Desta maneira a Dança deixava de ser apenas um aspecto de entretenimento e lazer.

Com o objetivo de promover um diálogo entre a minha experiência artística e a Educação Básica, durante os anos de 2002 e 2003, cursei a Especialização em Arte Educação da Pontifícia Universidade Católica de Minas Gerais / PREPES. Neste processo tive a possibilidade de formalizar um diálogo entre a Dança e o Ensino Regular, ou seja, a Dança como elemento constitutivo da formação humana na Educação Bási- ca. Conheci e tive aulas com professores importantes, entre eles, Ana Mae Barbosa que desde esta época é considerada uma grande referência na Arte Educação no Brasil. Como resultado apresentei a monografia que buscou investigar a dança nas origens da nossa civilização como um elemento importante da "Paidéia" grega, ou seja, no processo da formação e educação geral do homem grego. 0 resultado desta pesquisa corroborou a importância da dança na formação humana desde Grécia Antiga.

Em 2003, ingressei no Mestrado em Educação Tecnológica no Centro de Educação Tecnológico (CEFET-MG), na Linha de Pesquisa Filosofia da Ciência e da Educação com objetivo de desenvolver uma pesquisa que estabelecesse relações entre o uso de metáforas como recurso mediador no ensino da dança apoiados em obras de referência da área de Dança relacionando conceitos de linguagem como orientações espaciais. Busquei estabelecer uma relação explícita entre o uso metáfora no cotidiano dos professores e esses conceitos, isto é, sistematizar o uso de analogias e metáforas como recurso didático no ensino da dança.

Em 2007 dei início ao doutorado, desta vez no Programa de Pós-Graduação de Estudos Linguísticos PosLIN da UFMG na linha Estudos da Inter-relação entre Linguagem, Cognição e Cultura. A tese intitulada "Os gestos das mãos e a referenciação: investigação de processos cognitivos na narrativa oral" teve como objetivo contribuir para o estudo da linguagem e cognição e para o conceito de corporeidade (embodiment) buscando uma melhor compreensão de como o pensamento e a linguagem são, fundamentalmente, ligados à ação corporal. Foi um momento muito significativo em minha trajetória, pois tive a possibilidade de defender a importância do corpo e do gesto explorando o status cognitivo do gesto.

Ao refletir sobre a multiplicidade de caminhos percorridos posso dizer que tenho uma 
formação acadêmica caracterizada pela interdisciplinaridade, em que as questões ligadas ao ensino da dança, formação de professores e linguagem corporal, que permeiam os meus estudos, asseguram a coerência da minha trajetória. Com a ausência de um curso especializado em dança em Belo Horizonte, fiz escolhas para minha formação universitária que possibilitassem futuramente minha inserção profissional na academia.

\section{Arte da dança como um diferencial profissional: professora universitária}

Através de processo seletivo, ingressei em 2001 como docente no Curso de Pedagogia do Centro Universitário do UNI-BH permanecendo até fevereiro de 2011. Inicialmente minha contratação estava associada à demanda de professor para disciplina Arte Educação recém-inserida na estrutura curricular do Curso de Pedagogia. Também lecionei disciplinas no Normal Superior relacionadas a corporeidade e a Educação Infantil e anos iniciais do Ensino Fundamental.

Nesta mesma instituição atuei como professora da extensão do Centro Universitário
UNI-BH no Projeto social CRIANÇA CIDADÃ em parceria com o 5o Batalhão da a Polícia Militar. Por intermédio desse projeto, 120 crianças e adolescentes de 7 a 11 anos, dos aglomerados Havaí, Morro das Pedras e Ventosa tiveram acesso a noções de cidadania, direitos humanos, e participaram de oficinas de Música, Dança e Artes Visuais. Neste projeto era responsável pela oficina de dança, tanto na atuação direta com as crianças carentes quanto na formação e orientação das estagiárias do curso de Pedagogia Centro Universitário UNI-BH envolvidas neste projeto. Foi uma experiência na qual me deparei com a complexidade do contexto do Terceiro Setor e do potencial formador e transformador da Arte.

Neste projeto atuei com um grupo de crianças de classe social menos favorecida num contexto exclusão, abandono, desigualdades sociais além das situações de risco pessoal e social. Nossa proposta era defender o papel formador e transformador da Arte como possibilidade de fortalecimento da identidade cultural dessas crianças através de suas mais variadas linguagens e expressões num processo de formação para a vida e para a cidadania.

Figura 13 - Projeto social Criança Cidadã UNI-BH e Polícia Militar 2001 e 2002
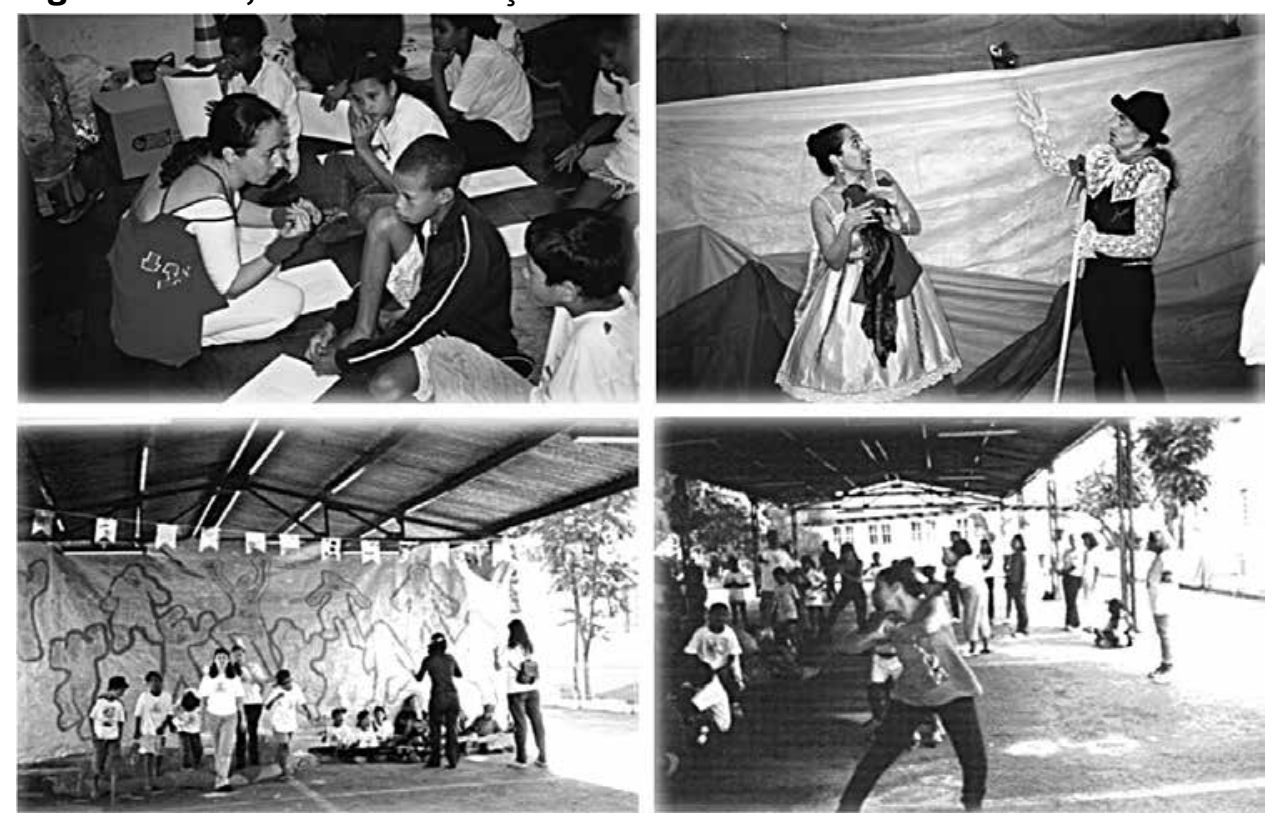

Fonte: Acervo da autora 
No período de 2005 até 2009 fui convidada pelo Professor Dr. Arnaldo Leite de Alvarenga da Escola de Belas Artes da UFMG para integrar o corpo docente do Curso de Extensão Pedagogia do Movimento para o Ensino de Dança na disciplina: Mediação de Processos Educativos na Dança I.

0 curso foi ofertado para professores de dança que já atuavam no mercado profissional, mas que necessitavam aprofundar seus conhecimentos sobre o seu ensino. Essa oferta atendeu profissionais não só da capital, mas, principalmente, do interior mineiro, uma vez que era realizado em dois finais de semana por mês, durante um ano. O curso surge como resposta à demanda da classe artística de Dança que, em determinado momento, se vê ameaçada de perder a sua identidade profissional com imposições de, por exemplo, sermos nomeados a partir de funções/ expressões usadas em outras áreas que não a nossa, totalmente destituídas do aspecto artístico, que na verdade é a nossa marca, o nosso diferencial.

Participar deste momento foi importante à medida que as experiências vividas e os conteúdos e disciplinas ministrados neste curso serviram de referência para a organização da proposta pedagógica do atual Curso de Graduação em Dança - Licenciatura da EBA/UFMG no qual atuo.

\section{Volta às origens: um sonho possivel}

Em 2010, candidatei-me ao Concurso de Professor Assistente do Curso de Graduação em Dança - Licenciatura da UFMG, que iniciaria sua primeira turma. Fui aprovada no concurso para a ÁREA DE CONHECIMENTO: Pedagogia para a dança e dança na educação. Foi o primeiro concurso para a formação do corpo docente do curso.
Como apresentado neste artigo, para aprender, estudar, ensinar, pesquisar e divulgar a área da Dança percorri uma trajetória em diferentes espaços/campos como cursos livres, pedagogia, linguística e cognição. Finalmente, com a aprovação no concurso essa trajetória culminou em meu ingresso no Curso de Graduação em Dança - Licenciatura da Escola de Belas Artes da UFMG.

Minha atuação docente no curso teve início no segundo semestre de 2010 como professora voluntária, devido à proibição de contratação no período eleitoral. Naquele momento, o mais importante é que o Curso de Dança deveria começar com professores da área. Um curso sonhado por muitos e por muito tempo. Era um projeto que ia além do meu sonho e do projeto de vida. Era o desejo e o sonho de um coletivo.

Um sonho que começa em 1956, quando foi criado na Universidade Federal da Bahia o primeiro curso de Graduação em Dança do país e na década de 90 com surgimento de cursos em São Paulo, Rio de Janeiro, Rio Grande do Sul e Paraná. Mesmo assim esta realidade configurava uma oferta muito limitada de Cursos Superiores de Dança no Brasil. Somente no contexto de expansão e democratização do ensino superior brasileiro é que houve a ampliação da oferta dos cursos de graduação em Dança, sendo que hoje temos mais de 40 cursos, entre eles a Licenciatura em Dança da Escola de Belas Artes da UFMG da qual faço parte como professora desde de sua criação em 2010.

Iniciei minha atuação na Pós-Graduação em Artes - PPGArtes da EBA/UFMG no ano de 2011 linha de pesquisa: Artes e Experiência Interartes na Educação. Em 2015, passei integrar o programa do Mestrado Profissionalizante PROFArtes da Escola de Belas Artes, na linha de pesquisa Abordagens teórico-metodológicas das práticas docentes com o objetivo proporcionar formação continuada a docentes de Artes da Educação Básica pública, propondo 
discussões sobre o papel do ensino da Arte na escola e na comunidade.

Como pesquisadora, destaco minha participação como idealizadora e líder do grupo de pesquisa Laboratório de Estudos do Gesto e Cognição (GESTOLab) da UFMG, criado 20 de junho de 2013 e registrado no CNPQ. O grupo busca dar condições aos seus integrantes de vivenciarem um espaço catalisador de processo de construção de conhecimento na área de Arte a partir da experimentação, discussão e reflexão de investigações sobre: formação em dança; gesto e cognição; linguagem corporal no contexto da educação infantil; papel das metáforas e analogias na construção do gesto artístico de dança, entre outros.

Ao longo do meu percurso na UFMG, tenho atuado em diversas ações extensionistas, como programas, projetos, cursos e eventos. Dentre elas, destaco o "Projeto Linguagem Corporal na Educação Infantil: Capacitação de Educadores da Rede Municipal de BH numa Perspectiva Teórico-Prática" vinculado à Pró-reitora de Extensão em parceria com a Gerencia de Educação Infantil (GEREDI) da Rede Municipal de Belo Horizonte que desde 2011 envolve a participação de Unidades Municipais de Educação Infantil (UMEl's), Escolas de Educação Infantil e Creches Conveniadas.

O objetivo do projeto é contribuir para uma formação docente que ressignifique a atuação do professor na Educação Infantil no que diz respeito ao ensino de dança propondo a "Residência Corporal" nas escolas de Belo Horizonte durante todo o ano letivo. Neste período acontecem encontros semanais desenvolvendo a experimentação em sala de aula com a Aula do corpo com a participação de professores e crianças, além da formação continuada semestral a partir de palestras para equipe pedagógica. Desenvolvemos um trabalho de ensino e aprendizagem em Linguagem Corporal: Dança na Educação Infantil que considere a criança protagonista deste processo e abra possibilidade para o adolescer da criatividade da criança pequena na criação de movimentos simbólicos e extracotidianos, bem como contribuir para o desenvolvimento integral da criança.

Um dos momentos mais importantes deste projeto acontece quando uma nova integrante da equipe, em sua segunda visita a uma das UMEl's encontra as crianças já do lado de fora da sala se preparando para iniciar as atividades. Ao avistá-la e ainda estranhando sua presença no projeto, duas crianças se aproximaram e questionaram a sua presença ali. - "O que você está fazendo aqui?" Indagou um dos meninos. Ao invés de respondê-las de imediato, ela pergunta para eles: - "Por que vocês acham que estou aqui?" E uma das crianças responde: "Eu já sei, é aula de dança!" E a outra criança instantaneamente, afirma: "É aula de mim!". E saíram os dois felizes pela liberdade que aquela aula propunha no meio da manhã de quarta-feira.

A poiesis da fala espontânea de uma criança de três anos ressoou em mim fazendo com que eu refletisse sobre toda a minha trajetória profissional, seja como professora de dança em cursos livres ou como professora em cursos de licenciatura. Uma experiência que teve início aos dois anos e meio no comercial de TV no qual atuei como protagonista utilizando minha linguagem corporal, depois como bailarina, professora de dança e professora universitária. Aula de Mim representava trazer a criança para o protagonismo de seu corpo, permiti-la ser propositora de seus próprios movimentos numa perspectiva estética.

\section{Professora-artista-pesquisadora} que segue...

Ao narrar momentos/fragmentos da minha trajetória como professora-artista-pesquisa- 
dora de dança seja em cursos livres, grupos de dança e, mais recentemente, os momentos que marcaram meu percurso na universidade constato a concretização de um sonho pessoal e ao mesmo tempo um sonho sonhado por muitos, um esforço que começou há muito tempo por outras gerações.

Nesta escrita de mim lembrar, juntar, relacionar, interpretar meu corpo, meu movimento, meu tempo e espaço deram forma própria as minhas experiências. Experiências que quando narradas revelam que dançar, ensinar dança, produzir dança, escrever sobre dança e viver a dança seria algo que me acompanharia por toda a vida.

Narrar a si mesmo é um procedimento que inscreve a história de vida em uma dinâmica que liga o passado, o presente e o futuro do sujeito e visa fazer emergir o seu projeto pessoal e profissional, como construção da experiência do sujeito e da sua trajetória de vida. Para DELORY-MOMBERGER (2006, p. 365) “[...] o impulso do projeto de si permite advir à perspectiva de uma história que desenha um futuro possivel e se concretiza em projetos singulares". Como resultado deste processo de "narrar a mim mesma" encontrei uma coerência e uma identidade em minha trajetória que serve de base para minhas perspectivas profissionais futuras. Continuar desenvolvendo uma proposta de formação docente de dança, seja no ensino, pesquisa e ou extensão que possa contribuir para o crescimento e aprimoramen- to da competência didática e artística dos profissionais numa perspectiva mais democrática e plural para que sejam capazes de ensinar a dança nas escolas garantindo o potencial formador e transformador da Arte.

\section{Referências}

BRASIL. Ministério da Educação (MEC). Secretaria de Educação Fundamental (SEF). Parâmetros Curriculares Nacionais: apresentação dos temas transversais, ética. Brasília, DF: MEC/SEF, 1997.

DELORY-MOMBERGER, Christine. Formação e socialização: os ateliês biográficos de projeto. Educação e Pesquisa, São Paulo, v. 32, n. 2, p. 359-371, maio/ago. 2006. Disponivel em: http://www.scielo.br/scielo. php?script=sci_arttext $\&$ pid $=$ S1517- 97022006000200 Acessado em: 11 jan. 2020.

DELORY-MOMBERGER, Christine. Abordagens metodológicas na pesquisa biográfica. Revista Brasileira de Educação, v. 17, n. 51, p. 523-740, set./dez, 2012. Disponivel em: http://www.scielo.br/pdf/rbedu/ v17n51/02.pdf Acessado em: 11 jan. 2020.

DELORY-MOMBERGER, Christine. A condição biográfica: Ensaios sobre a narrativa de si na modernidade avançada. Natal: UFRN, 2012a.

JOSSO, Mari-Christine. Experiências de Vida e Formação. São Paulo: Cortez, 2004.

VIANNA, Klauss. A Dança. São Paulo: Siciliano, 1990.

Recebido em: 30.09.2019

Revisado em: 11.01.2020

Aprovado em: 26.03.2020

Ana Cristina Carvalho Pereira é Professora associada da Escola de Belas Artes da Universidade Federal de Minas Gerais (UFMG) atuando no curso da Graduação de Licenciatura em Dança, no Programa de Pós-Graduação em Artes e no Mestrado Profissional em Artes (PROFARTES). É doutora pela UFMG com foco em Processamento da Linguagem, mestre em Educação Tecnológica pelo CEFET-MG. Líder do Grupo de Pesquisa Laboratório GESTOLab. E-mail: anacriscpereira@ig.com.br 